\title{
Trade Union Recognition in Britain, 1995-2002: turning a corner?
}

\author{
Abstract \\ This paper examines developments in union recognition in Britain between 1995-2002 \\ and assesses the influence of the statutory provisions for gaining recognition contained in \\ the Employment Relations Act 1999. The paper details the significant increase in the number \\ of new agreements, concluding that the new law is one amongst a number of factors \\ explaining this growth. Analysis is made of the nature and circumstances of the new \\ agreements. Finally, the paper considers whether these developments indicate the turning \\ of a corner for trends in recognition coverage.
}




\section{Trade Union Recognition in Britain, 1995-2002: turning a corner?}

\section{Introduction}

The statutory provisions for gaining union recognition in Britain, contained in the Employment Relations Act (ERA) 1999, came into force on 6 June 2000. This paper examines developments in union recognition since it became apparent that such provisions would come into force. This can be dated from 1995, when it became likely that Labour would win the next general election and legislate on its policy to establish a statutory mechanism for gaining union recognition where majority support existed amongst the workforce. From this point onwards, the tempo of debate and discussion amongst interested parties (government, media, political parties, employer associations and unions) about statutory recognition has heightened awareness amongst employers, unions and workers, exerting a powerful influence on their behaviour. Unions began organising significant numbers of campaigns for recognition and employers began preparing their responses. The paper details the significant increase in the number of new union recognition agreements concluded. It then analyses the context, nature and circumstances of this growth. Finally, it concludes by considering whether these developments indicate the turning of a corner for trends in union recognition coverage.

\section{Methodology}

The data for this research are derived from a number of sources. The first is material from the LRD-TUC Trade Union Trends surveys (1996-2003) on recognition, covering around $85 \%$ of TUC affiliated membership. Second, semi-structured interviews with regional field and national full-time officers (FTOs) from 15 unions who were either involved with or responsible for recognition campaigns. Officials from these unions were interviewed in 1999 (14), 2000 (20), 2001 (25) and 2002 (25). The third is information 
provided by the major employers' federations, through either interview or correspondence. The fourth is the monitoring of over thirty unions' journals and secondary IR sources for the last seven years. Lastly, the determinations of the Central Arbitration Committee (CAC) were used - 236 applications had been made by the end of 2002. From these sources, data was collected on the number and character of new agreements as well as the processes by which, and contexts in which, they were signed.

The data is, thus, extensive in its coverage but not inclusive of all new agreements and relevant developments because of poor information gathering and record keeping (as well as disseminating and publicising the data) within the different levels of unions, particularly at national levels. It is, however, more inclusive of actual developments than any other data set. For example, the Trends surveys report only on those agreements and campaigns that are identified to it through its surveys. Further, although the percentage of unions that respond to the Trends surveys by affiliated membership is high, this still means that many unions have not responded to each survey. The effect of these is offset by the use of the other data collection methods for this research, in particular interviews and monitoring union journals. However, again the poor record keeping within unions means that we can say with certainty that not all agreements and campaigns are known of. Similarly not all the details of reported agreements and campaigns are known of. What degree of overall 'underreporting' exists is impossible to state. But this research's data are, nonetheless, the most inclusive of any existing data on such developments (cf. IDS 2001, IRS 2000, 2002).

\section{Growth in New Recognition Agreements}


It is clear from Table 1 that there has been a significant increase in the last eight years in number of new agreements being signed (2246 in total). Concomitant, the phenomenon of derecognition appears to have been almost eclipsed. This stands in the context of cases of derecognition being of greater significance, despite being matched by cases of new agreements, in the early 1990s. In this regard, recognition may be turning a corner. Table 1 also shows that 725,000 workers have been brought under new agreements since 1995. This compares to some 41,000 workers covered by derecognition for the same period. Given these numbers constitute only known numbers (recognition - 69\% of cases, derecognition - $67 \%$ of cases), it is reasonable to suggest that the actual numbers covered by both are considerably higher. Using a simple average multiplier for unknown cases based on known cases, new recognition deals in the period may cover just over $1,000,000$ workers while cases of derecognition may cover 61,000 workers. And with the influence of the statutory provisions explaining much of the growth in agreements (see below), the extent of the growth is much greater than had been anticipated (cf. Ewing 2001:x, Hendy 2001:11, Morris 2001:69, Towers 1999:4).

Table 1. Reported New Recognition Agreements and Cases of Derecognition 1989-2002

\begin{tabular}{|c|c|c|c|c|c|c|}
\hline Year & Recog & ition & & Derecc & gnition & \\
\hline & $\begin{array}{l}\text { No. of } \\
\text { cases }\end{array}$ & $\begin{array}{l}\text { Known number's } \\
\text { covered (from no } \\
\text { of cases) }\end{array}$ & $\begin{array}{l}\text { Known } \\
\text { type of } \\
\text { recognition }\end{array}$ & $\begin{array}{l}\text { No. of } \\
\text { cases }\end{array}$ & $\begin{array}{l}\text { Known number's } \\
\text { covered (from } \\
\text { no of cases) }\end{array}$ & $\begin{array}{l}\text { Known } \\
\text { type of } \\
\text { derecognition } \\
\end{array}$ \\
\hline 1989 & 58 & $6,550(31)$ & 16 full, 7 partial & 52 & & \\
\hline 1990 & 49 & $5,120(33)$ & 17 full, 7 partial & 47 & & \\
\hline 1991 & 76 & $4,050(31)$ & 17 full, 16 partial & 62 & $73,000 \mathrm{a}$ & $\mathrm{n} / \mathrm{a}$ \\
\hline 1992 & 56 & $9,050(45)$ & 15 full, 6 partial & 75 & & \\
\hline 1993 & 57 & $5,270(18)$ & $\mathrm{n} / \mathrm{a}, \mathrm{n} / \mathrm{a}$ & 46 & & \\
\hline 1994 & 27 & $9,520(14)$ & 6 full & 15 & $3,800(6)$ & 13 full, 1 partial \\
\hline 1995 & 88 & $27,404(64)$ & 74 full, 11 partial & 66 & $15,931(42)$ & 28 full, 33 partial \\
\hline 1996 & 85 & $26,377(64)$ & 61 full, 13 partial & 54 & $16,851(46)$ & 25 full, 23 partial \\
\hline 1997 & 108 & $24,509(75)$ & 70 full, 10 partial & 31 & $4,362(17)$ & 15 full, 4 partial \\
\hline 1998 & 119 & $39,820(68)$ & 79 full, 6 partial & 7 & $432(4)$ & 3 full \\
\hline 1999 & 358 & $130,386(263)$ & 283 full, 18 partial & 11 & $1,210(9)$ & 6 full, 3 partial \\
\hline 2000 & 525 & $156,745(452)$ & 469 full, 6 partial & 4 & $1,700(3)$ & 1 full \\
\hline
\end{tabular}




\begin{tabular}{|l|l|l|l|l|l|l|}
\hline 2001 & $\mathbf{6 7 6}$ & $121,993(424)$ & 520 full, 7 partial & $\mathbf{5}$ & $108(1)$ & 1 full \\
\hline 2002 & $\mathbf{3 7 2}$ & $198,553(223)$ & 272 full, 19 partial & $\mathbf{9}$ & $760(3)$ & 1 full \\
\hline Totals & $\mathbf{2 6 5 4}$ & $\mathbf{7 6 5 , 3 5 7}(\mathbf{1 8 0 5})$ & $\mathbf{1 8 9 9}$ full, 126 partial & $\mathbf{4 8 4}$ & $\mathbf{1 1 8 , 1 5 4}(\mathbf{1 2 4})$ & $\mathbf{9 1}$ full, 64 partial \\
\hline
\end{tabular}

Sources: Data gathered from fieldwork. Gall and McKay (1999b:603) for years 1989-1998. However, up dated figures are provided for a number of these years.

Notes: (a) This figure is an aggregate for 1989-1993 (Gall and McKay (1994:436)). (b) Figures for 1994 are lower due to data collection methods (Gall and McKay 1999b:604).

The trends exhibited mirror a broadly similar picture emerging from ACAS (Table 2).

With derecognition, ACAS (1996-2001) records only 25 cases between 1995 and 2000.

The CBI’s (1998:21) 1998 Employment Trend Survey also reported similar findings, with only $2 \%$ of respondents derecognising unions in the last five years. Thereafter, union derecognition did not figure in CBI survey questions.

Table 2. Recognition Claims Involving ACAS 1989-2001

\begin{tabular}{|l|l|l|l|l|l|}
\hline Year & $\begin{array}{l}\text { No } \\
\text { of } \\
\text { completed } \\
\text { cases }\end{array}$ & $\begin{array}{l}\text { No } \\
\text { of } \\
\text { successful } \\
\text { cases }\end{array}$ & $\begin{array}{l}\text { Success } \\
\text { rate } \%)\end{array}$ & $\begin{array}{l}\text { Of these } \\
\% \text { full collective } \\
\text { bargaining rights } \\
\text { Bargaining }\end{array}$ & $\begin{array}{l}\text { \% partial } \\
\text { rights }\end{array}$ \\
\hline 1989 & 136 & 31 & 23 & 70 & 30 \\
\hline 1990 & 159 & 38 & 24 & 71 & 29 \\
\hline 1991 & 174 & 58 & 33 & 51 & 49 \\
\hline 1992 & 122 & 26 & 21 & 71 & 29 \\
\hline 1993 & 94 & 36 & 38 & n/a & / a \\
\hline 1994 & 87 & 32 & 37 & c50 & c50 \\
\hline 1995 & 100 & 51 & 51 & 57 & 43 \\
\hline 1996 & 109 & 65 & 60 & 57 & 43 \\
\hline 1997 & 94 & 54 & 57 & 60 & 40 \\
\hline 1998 & 125 & 62 & 50 & 69 & 31 \\
\hline $1999-2000$ & 148 & 78 & 52 & 67 & 8 \\
\hline $2000-2001$ & 264 & 174 & 66 & 92 & n/a \\
\hline $2001-2002$ & 337 & 216 & 64 & n/a & 35 \\
\hline Totals/Average & 1949 & 921 & 44 & 65 & \\
\hline
\end{tabular}

Source: ACAS Annual Reports.

Note: 1999-2000 covers the period 1 January 1999 to 31 March 2000. Thereafter, years are 1 April 2000 to 31 March. Previous years are calendar years.

At first sight, the picture emerging from data here contrasts markedly with that from WIRS. Millward et al (2000:96, 228) recorded recognition by establishment falling significantly between 1984 and 1998 (Table 3), attributing this largely to the low level of recognition amongst new and growing workplaces, because of low union membership 
densities rather than from derecognition in older workplaces. Furthermore, Millward et al (2000:103) reported from panel survey data that from 1990-1998 derecognition affected $6 \%$ of establishments and new recognition $4 \%$ of establishments, with this amounting to 56\% of establishments recognising unions in 1990 and 55\% in 1998.

Table 3 Coverage of Union Recognition and Collective Bargaining

\begin{tabular}{|l|l|l|l|l|}
\hline Year & $\begin{array}{l}\% \text { Establishments } \\
\text { covered by UR }\end{array}$ & $\begin{array}{l}\text { \% Workforce } \\
\text { covered by UR }\end{array}$ & $\begin{array}{l}\text { \% Establishments } \\
\text { covered by CB }\end{array}$ & $\begin{array}{l}\text { \% Workforce } \\
\text { covered by CB }\end{array}$ \\
\hline 1980 & 64 & $\mathrm{n} / \mathrm{a}$ & $\mathrm{n} / \mathrm{a}$ & $\mathrm{N} / \mathrm{a}$ \\
\hline 1984 & 66 & $\mathrm{n} / \mathrm{a}$ & $\mathrm{n} / \mathrm{a}$ & 70 \\
\hline 1990 & 53 & 54 & $\mathrm{n} / \mathrm{a}$ & 54 \\
\hline 1998 & 42 & 62 & $\mathrm{n} / \mathrm{a}$ & 41 \\
\hline
\end{tabular}

Sources: Column B-Millward et al (2000:96), Column C- Millward et al (1992: 107), Cully et al (1999:92), Column E- Cully et al (1999:242).

How can this divergence be explained? Firstly, what is being measured is different, in that WIRS measures existing and overall recognition levels while the data here measures new cases of recognition (and derecognition). Thus, the populations and the method of data collection are different whereby WIRS sampled while the data here is 'self-selecting' without a clearly known population sample. Secondly, different time periods are used by the data sets. In particular, data collection for WIRS ended in mid-1998 (Millward et al 2000:xv). Therefore, the two are not necessarily incompatible, for within the larger aggregate picture, more recent and internal trends are possible. This relates to the a third point. Data from the BSA and LFS surveys (Tables 4 and 5) indicate that the fall in recognition coverage has stopped and some growth has been recorded. This can be taken to suggest that the increase in new agreements and the fall in cases of derecognition has produced a small net increase in some recent years.

Table 4: British Social Attitudes surveys : percentage of people in workplaces with recognition

\begin{tabular}{|l|r|r|r|r|r|r|r|r|r|r|r|r|r|r|r|r|r|}
\hline Year & 1983 & 1984 & 1985 & 1986 & 1987 & 1989 & 1990 & 1991 & 1993 & 1994 & 1995 & 1996 & 1997 & 1998 & 1999 & 2000 & 2001 \\
\hline$\%$ & 66 & 63 & 62 & 62 & 62 & 58 & 58 & 58 & 56 & 54 & 55 & 50 & 50 & 49 & 47 & 48 & 47 \\
\hline
\end{tabular}

Source: Alex Bryson, Policy Studies Institute, personal e-mail communication run from British Social Attitudes surveys, 11 April 2003. 
Table 5: Union Recognition Coverage from the Labour Force Survey

\begin{tabular}{|l|l|l|l|}
\hline Year & $\begin{array}{l}\text { No of workers } \\
\text { covered by } \\
\text { recognition }(\mathrm{m})\end{array}$ & $\begin{array}{l}\text { \% change } \\
\text { from previous } \\
\text { Year }\end{array}$ & $\begin{array}{l}\text { \% of workers } \\
\text { covered by } \\
\text { Recognition }\end{array}$ \\
\hline 1993 & 10.42 & n/a & 48.9 \\
\hline 1994 & 10.374 & -0.4 & 48.2 \\
\hline 1995 & 10.226 & -1.8 & 46.8 \\
\hline 1996 & 10.141 & -0.8 & 45.8 \\
\hline 1997 & 10.032 & -1.1 & 44.3 \\
\hline 1998 & 10.081 & 0.5 & 43.5 \\
\hline
\end{tabular}

Source: Labour Market Trends (various).

Note: 'n/a'- not applicable as LFS started in 1993. After 1998, LFS questions were changed so continuing data on these three indices is not available. Data on union presence and coverage of bargaining is available after 1998. Thus, the number of employees whose pay is affected by collective agreements is the nearest proxy to those covered by recognition: 1999- 36.1\%, 2000-36.2\%, 2001- 35.6\% (Labour Market Trends 2002).

\section{Explaining Growth}

The growth in new agreements is explicable by virtue of the unions' organising activities, the ERA's 'shadow effect', employers' responses, and the 'new' climate in IR. Increasingly from the early 1990s, unions have recognised the significance of their decline (membership, organisational presence, bargaining power). Indications of this, and responses, are re-launching the TUC (1995), establishing the 'Organising Academy' (1997) and the spread of the 'organising culture' (Heery et al. 2000a, b, c). Recognition of the need to counter decline through self-reliance and self-activity has thus led to widespread activity in recruitment and organising. For example, between 1997-2002 the Trends surveys reported 750 campaigns for recognition, covering nearly 474,000 workers ${ }^{1}$. Although no comprehensive data for the 1990s exists, evidence from WIRS3 (Snape 1994:57-8), covering 1984-1990, indicates very limited recognition campaigning activity took place and little success was recorded. It is therefore be reasonable to suggest that there has been a substantial increase in the number and extent of recognition campaigns since the mid-1990s. Put simply, more campaigning for recognition has, in the current

\footnotetext{
${ }^{1}$ This figure is derived using an average calculator from the known numbers involved (363,434 from 634 cases). The total figure is cumulative and does not therefore include those campaigns that have 'dropped' out due to the gaining of recognition agreements.
} 
environment, led to more new agreements. The success of campaigns and the growth in new agreements from the mid-1990s has given unions further confidence to continue and widen their activities on this front. This union success has run in tandem with first the halting of overall membership decline and some small increases.

A crucial spur to these union activities has been the approach of the recognition provisions, i.e. their 'shadow effect'. They have added to an existing development - that of an orientation towards organising recognition campaigns, and engendered a sense of urgency and a concentration of minds. Each stage of the process of Labour policy eventually becoming enacted in law has been used by the unions as stimuli to their activities and to put further pressure on employers to grant recognition. As time progressed the imminence of the law exerted a stronger pressure, and is most clearly seen from 1999. Thus, the CBI commented: 'sensible HR directors are telling their boards to consider negotiating recognition deals while time is on their side and before the law imposes a statutory procedure' (Financial Times 9 February 1999).

Subsequently, imminence was replaced by the effect of presence and usage. Presence refers to not just the availability to recourse but also the cumulative and positive 'bandwagon' impact of the increasing number of new agreements being signed. Usage refers to threatened use, partial usage where an application is made and progressed to solicit a voluntary deal and (full) actual usage. Partial and actual usage has had a positive demonstration effect. Of the CAC applications by the end of 2002, 146 were accepted, 20 rejected and 68 withdrawn before decision on acceptance and admissibility. Of these, 23 were re-submitted. Fifty-one ballots have been conducted with union wins in 34 cases, 24 automatic awards have been made and 53 voluntary deals have been signed arising 
from applications. Furthermore, in the determination of bargaining units, 43 outcomes favoured the unions, twelve the employer and fourteen were not contentious. Following determination of bargaining units, five applications were withdrawn and a further five applications failed to meet the admissibility requirements. To many employers, such an outcome, even allowing for the relatively low number of applications and number of workers covered by the agreements, creates further pressure to sign (voluntary) agreements. The CAC is unlikely to have created the impression that it is a haven for recalcitrant employers (Younson 2002). Thus, unions, whether before or after June 2000, have been able to successfully put the case to employers that signing voluntary has a number of advantages over the statutory process; the process is potentially less cumbersome and drawn out, less public and less conflictual, and more purposeful control can be exerted to shape both the process of signing and the content of the agreement.

Turning to the employers, they now face a large number of requests and campaigns for recognition, as the CBI annual Employment Trends Surveys suggest (Table 6). The less extensive, by employer response, Dibb Lupton Alsop (2000) annual Industrial Relations Surveys for 1998-2000 also indicate that more companies are now being approached for recognition than previously. Thus, an array of employers is now being forced to consider and confront the issue of recognition in a more forceful way than before.

Table 6: Employers' Perception of Recognition Claims

\begin{tabular}{|l|l|l|l|l|}
\hline Year & Received & $\begin{array}{l}\text { Expect/ } \\
\text { Anticipate }\end{array}$ & Possible & $\begin{array}{l}\text { No of Respondents/ } \\
\text { Response rate })\end{array}$ \\
\hline 2002 & $\mathrm{n} / \mathrm{a}$ & $9 \%$ & $\mathrm{n} / \mathrm{a}$ & $940 / 9000(10 \%)$ \\
\hline 2001 & $9 \%$ & $7 \%$ & $\mathrm{n} / \mathrm{a}$ & $673 / 4800(14 \%)$ \\
\hline 2000 & $13 \%$ & $12 \%$ & $\mathrm{n} / \mathrm{a}$ & $829 / 5000(17 \%)$ \\
\hline 1999 & $\mathrm{n} / \mathrm{a}$ & $13 \%$ & $19 \%$ & $830 / 5000(17 \%)$ \\
\hline 1998 & $\mathrm{n} / \mathrm{a}$ & $10 \%$ & $18 \%$ & $671 / 5000(14 \%)$ \\
\hline
\end{tabular}

Source: CBI (1998- 2002)

Note: The surveys covered between $2.0 \mathrm{~m}-3.5 \mathrm{~m}$ workers in the private sector. 
Of the $13 \%$ receiving a request in the 2000 CBI (2000:19) survey, a third granted it, a third refused and a third were still considering it while in $200140 \%$ recognised or were likely to recognise a union with under a third rejecting recognition (CBI 2001:22). This suggests, in tandem with the ease by which many unions are gaining recognition, that a significant section of employers are exhibiting attitudes varying from neutrality to receptiveness when pressed. Further, many 'non-union' employers may not be 'antiunion' but rather have never been concerned or confronted with the issue before.

Examining employers who have granted recognition in more detail suggests many are displaying characteristics ranging from pragmatism to now a new-found concurrence with the 'business case' for trade unionism as well as elements of both. Thus, when faced with a well-supported recognition claim, defined by something approximating to majority workforce support and/or union membership and with the possibility of a statutory application, these employers have viewed the refusal to grant recognition as not conducive to 'good industrial relations' with regard to instability and tension in workplace relations. More generally, they are aware of the "way in which the wind is blowing' with regard to the success of unions gaining and employers granting recognition elsewhere. To them, it no longer seems an 'unusual' or 'outdated' course to take. However, the time taken to come to this view may be not inconsiderable (Tables 10 and 11). Pragmatism may border on opportunism.

Many employers, who previously did not recognise unions, are now also becoming convinced of, or sympathetic to, the 'business case'. This means they believe that workforce involvement and participation through recognition can lead to improved employee flexibility, productivity and satisfaction. They also see a virtue in having a partner to negotiate with over matters of industrial relations, which they believe bestows 
legitimacy on changes they seek to introduce in order to maintain or increase competitiveness or efficiency. Furthermore, it is believed that this method of communicating with their workforce is more efficient and effective compared to more 'individualised' ones. In a significant number of cases, the issue of employers' public image (particularly in public sector tendering) has been important in persuading companies to recognise unions, where they feel it will give them advantage in securing contracts. Many non-union employers have lessened their opposition to recognition as a result of the growing juridification of employment relations, in part, through the implementation of E.U. Directives into national law. Here unions are regarded as helpful in dealing with the more complex situation employers find themselves in. For these reasons, the Dibb Lupton Alsop (2002:22) surveys for 1998-2002 indicate an overall fall in the extent to which employers view unions as 'damaging' to their employment relations and an overall increase in the extent to which they view unions as 'benecial'. Although not inconsiderable, employer antipathy and hostility towards campaigns and requests for recognition is a more minor phenomenon (Gall and McKay 2001).

Finally, the period since Labour's election to government in 1997 has witnessed a relative renaissance in unions' public standing. While there are definite limits to this, and preferences for a certain type of trade unionism, recalling their position under Conservative governments (1979-1997) highlights the greater legitimacy and influence they now have in government and policy circles in Britain. Unions are now consulted in a far more extensive and meaningful way than previously. To some extent, this has occasioned unions' rehabilitation amongst employers so that they are taken as credible and influential bargaining partners and social agents. The promotion of 'partnership' has 'sweetened' what may be slightly 'bitter pill' for some. The Director of Scottish Engineering (Interview, 2001) believed 'partnership' had played some part in lessening 
unions' image as 'being stuck in the class war rhetoric of the 1970s'. These trajectories are supported and reinforced by two other factors, namely historically low strike rates and reductions in unemployment. Working days not worked per thousand workers have fallen in the 1990s, supporting the promotion of 'partnership' while falling levels of general unemployment have buttressed the potency of union campaigns.

However, some comment on this analysis is warranted. First, the data, particularly with regard to that from employers, does not allow for specific casual analysis to be made between the factors and the increased growth in voluntary agreements. Second, the preceding analysis for the period 1995-2001 is not invalidated by the fall in agreements in 2002. Rather, it suggests new and significant processes are in train. Unions have used up their existing pool of easy, winnable cases whose origins date from the 1990s. Concomitant, they are now facing the more difficult task of replenishing these by creating another tranche of strong cases (Table 6). Here, they face not just internal (union) resource and organisational issues but also the prospect of greater employer opposition vis-à-vis the remaining 'harder to crack nuts' and a hardening of anti-union attitudes amongst non-union employers between 2001-2002 (Dibb Lupton Alsop 2002:22). Third, a parallel to the fall in the rate of signing of agreements may be thought to exist in the renewed fall in overall union members. Membership stopped falling in 1998, grew in 1999 and 2000 but slipped back again in 2001 in both absolute and relative terms, albeit increases and decreases were marginal (Brook 2002:344). However, while both aggregate recognition coverage and membership density levels are closely related, in the case of the level of signing of new agreements and membership density, the relationship is not particularly close or straightforward. First, to the extent that new agreements involve new members, the newest of these are often several years old, and in many cases, members are long-standing. Second, though more new members are being recruited now than previously, unions are 'revolving 
doors' with gains to be set against losses (e.g. redundancies in unionised sectors in recent years). Third, much recruitment has been in 'in-fill' sites where recognition exists. Much of this is located in the public sector while the new recognition agreements are overwhelmingly in the private sector. Fourth, of the new agreements, few precede widespread and successful recruitment, the former being examples of unions 'recruiting' the employer first. Overall, this suggests the relationship is a relatively distant one and time lags may be involved.

\section{Obtaining Union Recognition: issues and processes}

\section{i) Recruitment and the choice of campaign}

With simple majority membership increasingly becoming the key to securing recognition as a result of the ERA, in most cases, unions seek to recruit first. The Trends surveys suggest that when membership is somewhere between $45 \%-55 \%$, unions identify the process as one of campaigning explicitly and directly for recognition (as opposed to continuing primarily with recruitment). Most FTOs reported they would not consider presenting a voluntary claim without at least 50\% membership of the bargaining unit. Others may settle for a lower target of around $40 \%$. Only a minority rejected obtaining such membership targets prior to initiating a recognition campaign. Instead, they considered whether the circumstances suggested that such a target was likely to be reached (and when), from a base of between 10\%-30\% membership, which they regarded as a credible basis for an approach. In these situations, unions also judge direct approaches may be viewed attractively where this may serve to block an approach from a less welcome union. In addition, the statutory provisions have also stimulated recognition campaigns amongst non-recognised members while increases in membership density were often encouraged by their imminence and presence as a result of workers' own awareness. 
Table 7: Reason for Recognition Campaigns, 1996-2002

\begin{tabular}{|l|l|l|l|l|l|l|l|}
\hline Reason/Year & 1996 & 1997 & 1998 & 1999 & 2000 & 2001 & 2002 \\
\hline Following an increase in membership & $33 \%$ & $29 \%$ & $31 \%$ & $51 \%$ & $58 \%$ & $55 \%$ & $53 \%$ \\
\hline Due to new legal right to recognition (impending/actual) & $\mathrm{n} / \mathrm{a}$ & $\mathrm{n} / \mathrm{a}$ & $\mathrm{n} / \mathrm{a}$ & $39 \%$ & $56 \%$ & $53 \%$ & $32 \%$ \\
\hline After union approach to employer & $40 \%$ & $32 \%$ & $31 \%$ & $26 \%$ & $28 \%$ & $28 \%$ & $22 \%$ \\
\hline Following a change in management/ownership & $20 \%$ & $16 \%$ & $13 \%$ & $8 \%$ & $26 \%$ & $21 \%$ & $15 \%$ \\
\hline Following privatisation and derecognition & $8 \%$ & $10 \%$ & $14 \%$ & $14 \%$ & $16 \%$ & $6 \%$ & $1 \%$ \\
\hline Following a change in bargaining arrangements & $12 \%$ & $9 \%$ & $5 \%$ & $8 \%$ & $15 \%$ & $9 \%$ & $6 \%$ \\
\hline Following an employer approach to the union & $4 \%$ & $6 \%$ & $6 \%$ & $\mathrm{n} / \mathrm{a}$ & $\mathrm{n} / \mathrm{a}$ & $\mathrm{n} / \mathrm{a}$ & $\mathrm{n} / \mathrm{a}$ \\
\hline
\end{tabular}

Source: Trade Union Trends (1996-2203).

Note: Respondents chose one or more reasons or none, producing totals greater or lesser than 100\%. Data for 1996, 1997 and 1998 averaged from bi-annual surveys.

Most FTOs reported recruitment began, and thus recognition campaigns, either after an approach to the union from individual workers or where a union member had gone to work in a previously unorganised workplace. In either case, the prevalence of widespread workplace grievances was necessary to stimulate approaching a union to undertake recruitment. Therefore, most officials saw cold recruitment (leafleting, holding meetings outside work and other methods of contacting workers) as less effective and less satisfactory. Although some officials might hold 'wish lists' of companies they wish to target (often gleaned from telephone or business directories), at a local level they tended to wait for approaches. This may explain why unions are reluctant to tackle new workplaces (Millward et al 2000, Machin 2000) - it may not be so much resistance to the 'new', so much as an understanding, gained from experience, of the difficulty of recruiting where there is no membership base. Thus, most FTOs stress the key is contacts within the workplace which are willing to recruit, organise and provide information. Where some differ is in their view of the best point at which formal organisation should be established. Some encourage its creation at an early stage in the belief that this holds the new membership together better. Others prefer to wait until a critical mass of members has been gained. Exceptions exist where sufficient resources exist to be able, on certain occasions, to commit personnel to undertake sustained activity over a six-month to year period in a single workplace/employer, or where an 
employer approaches a union seeking to sign an agreement, subject to attaining certain membership levels.

Being so dependent on external events makes it more difficult for unions to strategically plan recognition campaigns. ${ }^{2}$ This contributes to unions carrying too many campaigns at one time, diluting limited resources. Strategic planning, where it takes place at all, is more likely to be co-ordinated at national level, involving approaches to large employers with a number of establishments or amongst those regarded as 'blue-chip' or 'household name' companies. Unions with relatively strong regional organisation, like the T\&G and GMB, are less likely to rely on their head offices to identify recruitment targets. While this gives the union at local level the advantage of being able to campaign at a point in time when it believes that it will be most successful, it can result in situations where recognition is secured in one part of a company but not in another. Additionally, without nationally coordination, unions are less likely to be able to utilise information about recognition in one area of a company to put help pressure on another.

Campaigns to attain such required membership levels have comprised mapping exercises (for potential members and activists), recruitment and organising meetings and attempts to service existing members to display membership benefits. From this basis, petitions, ballots, political support, newspaper coverage and ACAS services have been used to try to gain recognition. These latter activities serve two main purposes; to demonstrate membership levels to employers, existing and potential members and to demonstrate to these groups the continuing level of union activity. Occasionally ballots for strikes and industrial action itself have been used (cf. Cully et al 2000:105).

\footnotetext{
${ }^{2}$ This, and the preceding discussion appear, at first sight, to sit rather uneasily with some of Heery et al's. (2000a, 2000b, 2000c, 2003) findings. However, the two are not necessarily in contradiction for not all unions are equally strategic in approach and elements of strategy can be found after location of campaigns is determined.
} 
Table 7 suggests two recent developments concerning how recognition campaigns come about. First, the influence of the statutory procedure, as a single and direct force, is now becoming accepted as part of the IR landscape such that its 'newness' is now waning. Second, and related to the fall in derecognition, campaigns following derecognition are becoming fewer. This is accentuated by many cases of recognition being won after derecognition where following derecognition membership levels and union organisation were maintained, so allowing these cases to be amongst the first to be won under the ERA's influence.

Broadly speaking, Table 8 shows that the majority of campaigns are consistently amongst employers or workforces of a small or medium size ( $<500$ workers), indicating the difficulty of campaigning amongst sets of large numbers of workers ( $>500$ workers). Indeed, both the absolute and relative number of campaigns amongst large workforces has fallen since 1997. Thus, although the number of campaigns has grown significantly, the number of workers covered has not increased proportionately. There is also some evidence that workplaces, where there are campaigns, are larger, on average, than those where recognition is eventually gained (Table 14), again suggesting that workplaces with large workforces, which are often physically dispersed on one or many sites, present unions with more of a challenge. But the proportion of campaigns in workplaces with 100 or fewer workers is comparable with that where recognition is secured (Table 14).

Table 8: Number of workers in each campaign, 1996-2002

\begin{tabular}{|l|l|l|l|l|l|l|l|l|}
\hline Year/No. of Workers & 1996 & 1997 & 1998 & 1999 & 2000 & 2001 & 2002 & $\begin{array}{l}1995-2001 \\
\text { average/(totals) }\end{array}$ \\
\hline $1-50$ & $30 \%$ & $35 \%$ & $25 \%$ & $43 \%$ & $27 \%$ & $25 \%$ & $\mathrm{n} / \mathrm{a}$ & $31 \%$ \\
\hline $51-100$ & $9 \%$ & $17 \%$ & $30 \%$ & $22 \%$ & $27 \%$ & $20 \%$ & $\mathrm{n} / \mathrm{a}$ & $21 \%$ \\
\hline $101-250$ & $17 \%$ & $17 \%$ & $28 \%$ & $17 \%$ & $33 \%$ & $29 \%$ & $\mathrm{n} / \mathrm{a}$ & $23 \%$ \\
\hline $251-500$ & $19 \%$ & $5 \%$ & $10 \%$ & $12 \%$ & $11 \%$ & $10 \%$ & $\mathrm{n} / \mathrm{a}$ & $12 \%$ \\
\hline
\end{tabular}




\begin{tabular}{|l|l|l|l|l|l|l|l|l|}
\hline $501-1,000$ & $8 \%$ & $9 \%$ & $5 \%$ & $3 \%$ & $2 \%$ & $7 \%$ & n/a & $6 \%$ \\
\hline $1,001-5,000$ & $8 \%$ & $9 \%$ & $2 \%$ & $0 \%$ & $0 \%$ & $7 \%$ & n/a & $4 \%$ \\
\hline $5,001-10,000$ & $3 \%$ & $4 \%$ & $0 \%$ & $3 \%$ & $0 \%$ & $2 \%$ & n/a & $2 \%$ \\
\hline $10,000+$ & $6 \%$ & $4 \%$ & $0 \%$ & $0 \%$ & $0 \%$ & $0 \%$ & n/a & $1 \%$ \\
\hline No. of campaigns & 59 & 97 & 106 & 143 & 149 & 144 & 104 & $802(114)$ \\
\hline $\begin{array}{l}\text { Known no of workers } \\
\text { covered/ from no of } \\
\text { cases) }\end{array}$ & $\mathrm{N} / \mathrm{a}$ & $\begin{array}{l}108,834 \\
(97)\end{array}$ & $\begin{array}{l}59,680 \\
(106)\end{array}$ & $\begin{array}{l}70,872 \\
(143)\end{array}$ & $\begin{array}{l}34,870 \\
(91)\end{array}$ & $\begin{array}{l}89,178 \\
(93)\end{array}$ & $\begin{array}{l}24,981 \\
(97)\end{array}$ & $\begin{array}{l}388,415 \\
(64,735)\end{array}$ \\
\hline Ave. no of workers & $\mathrm{N} / \mathrm{a}$ & 1,122 & 563 & 495 & 383 & 598 & 257 & 569 \\
\hline
\end{tabular}

Source: Trade Union Trends (1996-2003).

Note: Data for 1996, 1997 and 1998 averaged from bi-annual surveys.

\section{ii) Personnel and Resources for carrying out campaigns}

Unions at local and regional levels, compared to national level, are less likely to have budgets for campaigns, tending to rely on general funds to support campaigns. With national level campaigns, there are more likely to be specified budgets. The advantage of this is that officials know that there are funds at their disposal. The disadvantage is that it may result in the campaign being wound up earlier than it might have been, merely because the allocated funds have run out. Campaigns have normally been carried out by FTOs or dedicated full-time recruiters, rather than by lay activists from within or without the targeted employer. This contrasts with the 'organising model' and arises for three main reasons. Firstly, major unions like the AEEU, TGWU and GMB do not appear to have signed up to the 'organising' approach (Heery et al 2000a, b, c). They maintain a relatively centralised non-lay approach. Secondly, these unions appear to use lay activists (and in particular retired members) for initial recruitment. When the stage is reached where a campaign for recognition is to be launched, then the focus shifts to FTOs. Thirdly, (and even where there is support for the organising approach), the widespread difficulties of developing a cadre of lay activists (the 'organising committees'), particularly within those unrecognised workplace where there is some employer hostility, increases reliance on FTOs. 
When asked, most FTOs stated employers' attitudes were irrelevant to deciding whether or not to campaign for recognition. This is, to some degree, buttressed by the influence of the new statutory provisions and confirmed by their role in securing recognition (Tables 7 and 9). But changes in ownership or management appear to be slightly more significant when it comes to stimulating campaigning than securing recognition deals (Tables 7 and 9). Some unions vary their strategy dependent on whether the employer is perceived as receptive, hostile or neutral/agnostic - they are more likely to threaten to use or actually use the new law against employers perceived as hostile. The so-called process of 'recruiting the employer' is one that is common but far from dominant (Table 7). A failure do to so may incline the union to mount a 'full-blooded' campaign. Nonetheless, to many unions 'recruiting the employer' makes financial and resource sense where a union is trying to gain recognition from a multi-site employer or where the single-site employer has a large workforce spread through many sections or departments. In both, labour turnover may be considerable. Resource constraint means that it can be a difficult task trying to build up membership across all the various sites and departments. Signing a 'partnership' deal that includes facilities to recruit thereafter provides unions with one avenue to short-circuit the longer and more arduous process. But the cost is often a weak agreement because the union has not bargained from a position of strength.

\section{Conditions of success}

This section examines a number of conditions for and of success in signing new agreements. The former refers to conditions that are necessary to gain recognition, the latter to conditions when recognition was gained but where it is unclear of their relative necessity for success. Firstly, union perception of reasons for gaining new recognition 
agreements is considered (Table 9). Secondly, length of the campaigns, union density and support in ballots where recognition is gained are examined.

Table 9: Reason for Gaining Recognition

\begin{tabular}{|l|l|l|l|l|l|l|l|}
\hline Reason/Year & 1996 & 1997 & 1998 & 1999 & 2000 & 2001 & 2002 \\
\hline After union approach to employer & $41 \%$ & $26 \%$ & $25 \%$ & $53 \%$ & $45 \%$ & $71 \%$ & $74 \%$ \\
\hline Following an increase in membership & $17 \%$ & $9 \%$ & $22 \%$ & $44 \%$ & $41 \%$ & $80 \%$ & $54 \%$ \\
\hline After a union recruitment campaign & $23 \%$ & $17 \%$ & $16 \%$ & $34 \%$ & $34 \%$ & $72 \%$ & $73 \%$ \\
\hline Due to new legal right to recognition (actual/impending) & $\mathrm{n} / \mathrm{a}$ & $\mathrm{n} / \mathrm{a}$ & $\mathrm{n} / \mathrm{a}$ & $19 \%$ & $24 \%$ & $79 \%$ & $34 \%$ \\
\hline Following a change in management/ownership & $8 \%$ & $6 \%$ & $25 \%$ & $23 \%$ & $10 \%$ & $12 \%$ & $3 \%$ \\
\hline
\end{tabular}

Source: Trade Union Trends (1996-2003).

Note: Respondents can enter one or more reasons or none, producing totals greater or lesser than $100 \%$. Data for 1996, 1997 and 1998 averaged from bi-annual surveys.

Table 9 shows that a direct approach to the employer, involving discussions and negotiations, is an important step to securing recognition, but increasingly, it is being done from a basis of high union density (following a membership increase, after recruitment campaign) in tandem with the use of the statutory provisions' influence. This illustrates the continuing importance of the employer view: campaigns are increasingly less likely to seek employer approval (Table 7) but employer consent and cooperation are still necessary for successful outcomes.

Looking at campaign length, the majority (57\%) achieved recognition within a relatively short period of time, defined as less than two years (Table 10). This, and the number of campaigns which are initially reported but then subsequently not (of which many may be presumed to have been 'dropped'), suggest capitalising on workers' and members' initial enthusiasm and the resultant momentum is important because maintaining membership without recognition, where the degree of service and protection that can be delivered is minimal, is difficult. The need for early capitalisation is further predicated on the limited resources that FTOs can provide to any one workplace and the difficulty in building up and sustaining milieu of lay activists. 
Most FTOs reported they regularly reviewed campaigns to decide on whether they should continue. Some claimed that it was 'rare to end a campaign' and rather it is merely wound down or allowed to wind down. However, it is clear from the number of campaigns reported on that most unsuccessful campaigns are more than just 'wound down'. Rather, they are effectively abandoned and that the number of campaigns that do not record success or have not recorded success to date is large. It is, therefore, only the sheer number of campaigns that has produced the sharp increase in new agreements. The reasons for the poor 'strike rate' are various, namely, financial and human resources (rather than worker antipathy) and anti-union employer tactics. What is of particular note, is that unions are reporting as 'campaigns' activities that do not necessarily amount to very much either in content or longevity. In terms of resources, rather than commitment to organising, this may indicate that the unions are spreading themselves too thinly and do not have the means to maintain campaigns where success is not quickly forthcoming.

Table 10: Known Length of successful union recognition campaigns 1995-2002

\begin{tabular}{|l|l|}
\hline Years & No of Cases \\
\hline$<1$ & 92 \\
\hline$>1-<2$ & 109 \\
\hline$>2-<3$ & 40 \\
\hline$>3-<4$ & 14 \\
\hline$>4-<5$ & 11 \\
\hline$>5-<6$ & 5 \\
\hline$>6-<7$ & 12 \\
\hline$>7-<8$ & 19 \\
\hline$>8->9$ & 9 \\
\hline$>9-<10$ & 8 \\
\hline$>10+$ & 34 \\
\hline Total & 353 \\
\hline
\end{tabular}

Source: Data gathered from fieldwork.

In a minority of cases $(25 \%)$ successful campaigns took considerably longer, defined as over five years. Although these did not necessarily consist of constant activity, the 
statutory provisions' imminence and presence were helpful in revitalising members' determination and putting further pressure on the reluctant employer. Thus longstanding union membership and presence can be potentially be rewarded with recognition. In these cases, strong occupational identities (e.g. journalists, printers, steel workers) and unions (e.g. GPMU, ISTC, NUJ) which have experienced widespread derecognition and require re-recognition to re-establish themselves, are predominant.

Given the ERA's stipulation of membership and support thresholds $(50 \%+1$ in automatic awards, $50 \%+1$ in ballots which also equates to $40 \%+$ of all those entitled to vote), it is salient to examine how these have affected voluntary agreements. Where recognition has been gained without a ballot, union density has exceeded $50 \%$ in $70 \%$ of cases (Table 11). This points to union reticence to request recognition without such levels of membership given the ERA's influence, and, where membership is in excess of 70\%, significant employer antipathy and hostility (Gall 2003, Gall and McKay 2001). But this should not exclude cognisance of the many instances $(21 \%$ of cases $)$ where recognition has been gained with levels of density below $40 \%$. Amongst these are the examples of 'sweetheart deals' and those where employers' desire to conclude quick voluntary deals when facing inter-union competition is important. Recruitment then takes place after recognition. In many, but not all, cases ACAS's services were used to conduct membership audits. Table 11 includes those agreements that involved either CAC applications or automatic awards. In neither was the average level of union density at which recognition was granted markedly different to those secured without any formal recourse to the CAC.

Table 11: Union Recognition Granted 1995-2002: known union density level

\begin{tabular}{|l|l|}
\hline Density & No of Cases \\
\hline$>90 \%$ & 37 \\
\hline $80-89 \%$ & 34 \\
\hline
\end{tabular}




\begin{tabular}{|l|l|}
\hline $70-79 \%$ & 39 \\
\hline $60-69 \%$ & 61 \\
\hline $50-59 \%$ & 49 \\
\hline $40-49 \%$ & 28 \\
\hline $30-39 \%$ & 22 \\
\hline $20-29 \%$ & 20 \\
\hline $10-19 \%$ & 9 \\
\hline $0-9 \%$ & 14 \\
\hline Total & 313 \\
\hline
\end{tabular}

Source: Data gathered from fieldwork.

The number of (identified) recognition ballots taking place between 1995-2002 (including 51 CAC cases) was 209; three in 1995, six in 1996, twelve in 1997, fourteen in 1998, twenty in 1999, forty-six in 2000, sixty-seven in 2001 and 40 in 2002. Most have been organised through ACAS. Ballots, unlike before, have now become a prime method of assessing worker support for recognition where employers are more likely to insisting on them and unions are more likely to accept them. Table 12 shows the known results for 163 cases where recognition was gained. The levels of both turnout and support for recognition have been high, indicating the unions are performing well, although it is interesting to note that in $15 \%$ of cases recognition was granted where less than $40 \%$ of those entitled to vote voted for recognition. Of the remaining 46 cases, in 26 cases the ballots were lost and in the remainder recognition was gained but the respective figures are not known. Union success has resulted from strong campaigns and/or high levels of existing union membership.

Table 12: Known Ballots Results where Recognition Gained

\begin{tabular}{|l|l|l|l|}
\hline $\begin{array}{l}\text { Level of support } \\
\text { /No. of cases }\end{array}$ & Turnout & Vote For & $\begin{array}{l}\text { Overall Support } \\
\text { ('turnout' x 'vote for') }\end{array}$ \\
\hline $90-100 \%$ & 32 & 63 & 7 \\
\hline $80-89 \%$ & 35 & 55 & 12 \\
\hline $70-79 \%$ & 29 & 23 & 18 \\
\hline $60-69 \%$ & 22 & 11 & 25 \\
\hline $50-59 \%$ & 13 & 6 & 28 \\
\hline $40-49 \%$ & 1 & 5 & 21 \\
\hline $30-39 \%$ & & & 18 \\
\hline $20-29 \%$ & & & 1 \\
\hline No. of ballots for & 132 & 163 & 130 \\
\hline
\end{tabular}


\begin{tabular}{|l|l|l|l|}
\hline which data exists & & & \\
\hline
\end{tabular}

Source: Data gathered from fieldwork.

Despite the recent rise in ballots and membership audits, carried out largely through ACAS (ACAS 2000, 2001), most new agreements are signed without such ACAS involvement. By taking the annual number of new agreements (Table 1) and comparing ACAS's annual numbers of completed conciliation cases on recognition and those of recognition deals signed through ACAS (Table 2), it is clear the former heavily outweighs either of the latter after 1998. Therefore, most unions have secured recognition by building up membership density and making this apparent to employers. Where unions stated they have majority membership, employers can broadly verify their claims by soundings taken by line management. This would suggest that neither ballots nor formal membership audits are used by most employers to verify union claims.

\section{Union Activity in Signing New Agreements}

Table 13 shows the number of reported deals signed by individual unions between 19972002. The data largely supports individual union's claims to have signed a large number of deals (Inset 1). Taking size of union as an indicator of expected activity, one might expect the larger unions to be the most active. This is the case for the AEEU, GMB and TGWU but not MSF and Unison. The latter have large memberships in the public sector which reduces the potential for new agreements but this does not fully explain MSF's relative inactivity. By contrast, the GPMU has been extremely active for a union of its medium size, although this also reflects the dispersed nature of its members amongst many small employers. The activity of public sector unions like PCS and Unison indicates the degree to which they are now active outside the public sector. Some unions do not appear to be very active. Often this is for good reason; in-fill recruitment where recognition exists is cheaper and more cost-effective. 
Table 13: Number of Reported Deals Signed by Individual Unions 1997-2002

\begin{tabular}{|c|c|c|c|c|c|c|c|}
\hline Union/Year & 1997 & 1998 & 1999 & 2000 & 2001 & 2002 & Totals \\
\hline AEEU (then Amicus from 2002) & 19 & 26 & 48 & 34 & 156 & 80 & 363 \\
\hline ASLEF & & & & 1 & & & 1 \\
\hline BALPA & & 2 & 2 & 11 & 2 & 3 & 20 \\
\hline BECTU & & 3 & 8 & 1 & 4 & 5 & 21 \\
\hline BFAWU & 1 & 2 & 8 & 7 & 9 & 4 & 31 \\
\hline Connect & & & & 5 & & 2 & 7 \\
\hline CWU & 1 & 1 & 2 & 6 & 3 & 5 & 18 \\
\hline EMA (see Prospect from 2002) & & & & 5 & 5 & 5 & 15 \\
\hline GMB & 21 & 25 & 61 & 112 & 109 & 26 & 354 \\
\hline GPMU & 6 & 4 & 24 & 45 & 107 & 39 & 225 \\
\hline IPMS (then Prospect from 2002) & & 2 & 8 & 10 & 3 & & 23 \\
\hline ISTC & & 2 & 8 & 5 & 21 & 22 & 58 \\
\hline IUHS & & 1 & 2 & 1 & & & 4 \\
\hline KFAT & 1 & 3 & 4 & 2 & 5 & & 15 \\
\hline MSF (see Amicus for 2002) & 13 & 5 & 23 & 15 & 37 & & 93 \\
\hline NUJ & & & 3 & 10 & 24 & 31 & 68 \\
\hline NUMAST & & 5 & 2 & 4 & 1 & 5 & 24 \\
\hline PCS & 6 & 2 & 10 & 11 & 4 & 2 & 35 \\
\hline RMT & & & 4 & 2 & & 2 & 8 \\
\hline TGWU & 25 & 22 & 101 & 198 & 107 & 77 & 530 \\
\hline TSSA & 2 & & 4 & 1 & 3 & 2 & 13 \\
\hline UCATT & & 1 & 3 & 2 & 2 & 1 & 9 \\
\hline UNIFI & 8 & 5 & 8 & 7 & 3 & 4 & 35 \\
\hline Unison & 5 & 7 & 9 & 18 & 24 & 21 & 84 \\
\hline URTU & & & & & 4 & 1 & 5 \\
\hline USDAW & & 1 & 14 & 6 & 10 & 4 & 35 \\
\hline Others & & & 2 & 6 & 25 & 28 & 61 \\
\hline Totals & 108 & 119 & 358 & 525 & 675 & 369 & 2154 \\
\hline Multi-union deals & 1 & 3 & 4 & 10 & 29 & 13 & 60 \\
\hline
\end{tabular}

Source: Data gathered from fieldwork.

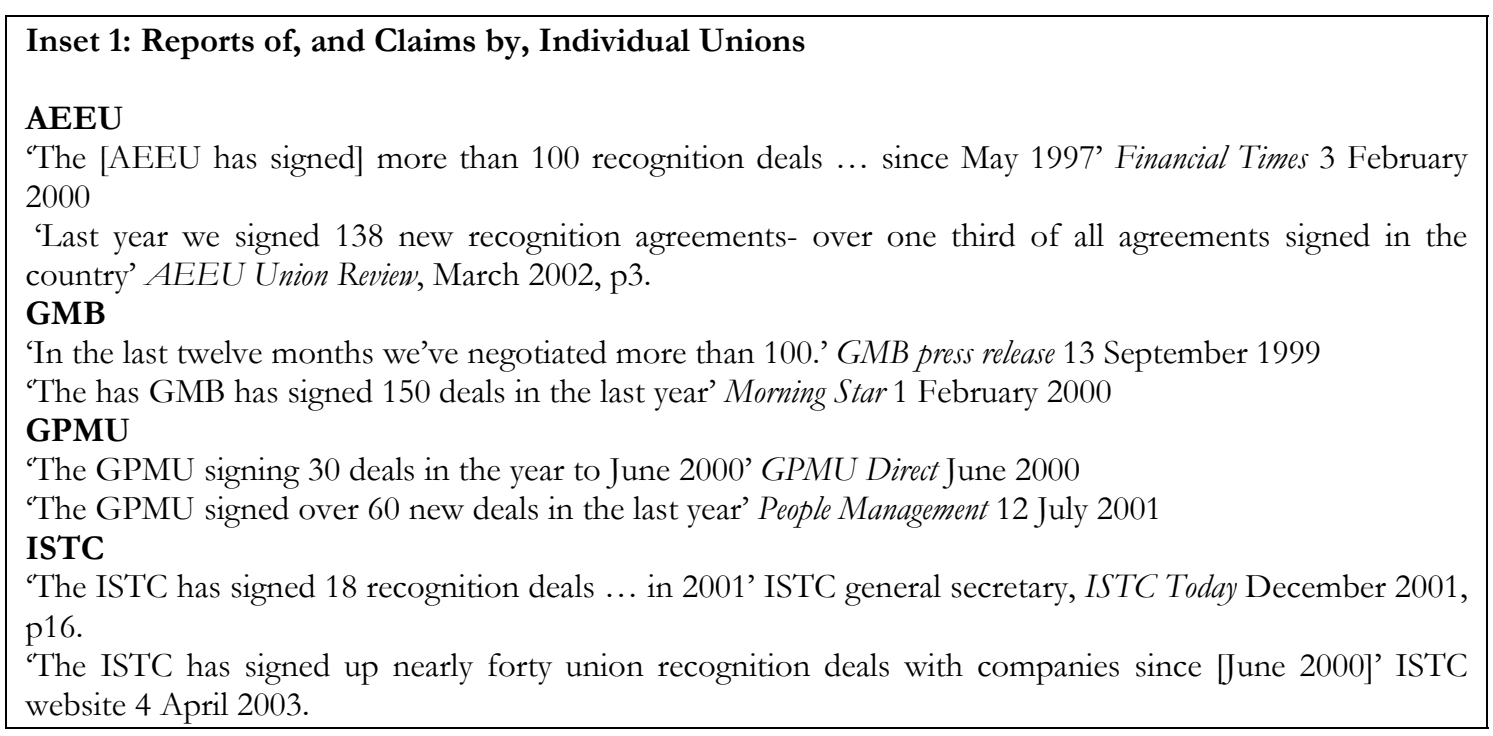




\section{NUJ}

'NUJ general secretary Jeremy Dear said the union had signed 70 new recognition agreements since the new laws hit the statute books' GPMU website 1 May 2003.

Prospect

'Since January 2000, Prospect - which combines the expertise of the IPMS with the EMA - has signed over 25 recognition deals' Prospect press release, 7 November 2001

TGWU

'The T\&G has signed full recognition agreements with approaching two hundred companies up and down the UK over the last year.' TGWU Press Release 2 February 2001

\section{Characteristics of New Recognition Agreements}

The location of the new agreements is heavily skewed towards the private sector, and in particular, general manufacturing, and, to a lesser extent to areas that were formally in the public services sector. Only a small proportion is in the private service sector, such as call centres, retail, business services and hotels/restaurants. In line with this, around $80 \%$ of individual deals concern manual workers. The remainder are white-collar workers (office staff, technicians, supervisors) or professionals. Nonetheless, there are some indications of new ground being broken. Just 6\% of new agreements since 1995 overturn previous derecognition and less than $4 \%$ are for extensions of recognition from existing agreements to other parts of an organisation. Thus, 90\% of new agreements are found where there has been no recognition before. And 95\% are for full recognition. Less than $3 \%$ are for (single) multi-union agreements (Table 13), but another $4 \%$ comprise multiunion recognition where, particularly in road transport, employers signed agreements with different unions for their different sites. A minority of multi-site employers are granting recognition on a site-by-site basis over time, albeit to the same union. Table 14 indicates that in most years $75 \%$ of agreements cover less than 250 workers, but a small number of agreements covering large numbers are significant to aggregate figures.

Table 14: Number of workers covered by each new agreement, 1995-2002

\begin{tabular}{|l|l|l|l|l|l|l|l|l|l|}
\hline Year/No of Workers & 1995 & 1996 & 1997 & 1998 & 1999 & 2000 & 2001 & 2002 & $\begin{array}{l}1995-2002 \\
\text { average }\end{array}$ \\
\hline $1-50$ & $35 \%$ & $40 \%$ & $30 \%$ & $24 \%$ & $22 \%$ & $26 \%$ & $43 \%$ & $34 \%$ & $32 \%$ \\
\hline $51-100$ & $17 \%$ & $14 \%$ & $26 \%$ & $11 \%$ & $18 \%$ & $28 \%$ & $23 \%$ & $26 \%$ & $20 \%$ \\
\hline
\end{tabular}




\begin{tabular}{|l|l|l|l|l|l|l|l|l|l|}
\hline $101-250$ & $31 \%$ & $26 \%$ & $31 \%$ & $18 \%$ & $22 \%$ & $21 \%$ & $16 \%$ & $18 \%$ & $23 \%$ \\
\hline $251-500$ & $6 \%$ & $8 \%$ & $7 \%$ & $24 \%$ & $12 \%$ & $12 \%$ & $10 \%$ & $10 \%$ & $11 \%$ \\
\hline $501-1,000$ & $4 \%$ & $3 \%$ & $2 \%$ & $13 \%$ & $16 \%$ & $5 \%$ & $2 \%$ & $5 \%$ & $6 \%$ \\
\hline $1,001-5,000$ & $6 \%$ & $8 \%$ & $3 \%$ & $8 \%$ & $9 \%$ & $5 \%$ & $4 \%$ & $5 \%$ & $6 \%$ \\
\hline $5,001-10,000$ & $1 \%$ & $1 \%$ & & $1 \%$ & $1 \%$ & $2 \%$ & $1 \%$ & $1 \%$ & $1 \%$ \\
\hline $10,000+$ & & & $1 \%$ & $1 \%$ & & $1 \%$ & $1 \%$ & $1 \%$ & $\mathrm{c} 1 \%$ \\
\hline Ave. no of workers & 428 & 412 & 326 & 585 & 495 & 346 & 287 & $890(488)$ & $471(420)$ \\
\hline
\end{tabular}

Source: Data gathered from fieldwork (and Gall and McKay (1999).

Note: In 2002, the TGWU signed a national enabling recognition agreement with Compass covering 90,000 workers. Under this agreement, local agreements are to be worked out. If this deal is excluded for the purposes of its unusual size, the average number of workers covered in 2002 falls dramatically and also has some effect on the 1995-2002 average.

Only a small percentage of new agreements are 'partnership' and/or 'sweetheart' agreements', even though there is considerable pressure from employers and government to sign these. Some unions may call agreements 'partnership' agreements regardless of what they are in practice. Taking what the unions themselves say are partnership agreements (where this is reported) and what are deemed to be by third parties (i.e. media commentators), less than $18 \%$ of the 2246 new agreements since 1995 fall into this category. Similarly, the frequency of single union deals (some which are also 'partnership' agreements) is small: only $7 \%$ of agreements comprised 'beauty contests' or the employer signing a deal with one union to exclude another. But as before (Gall 1993), the importance of such agreements is never simply their numerical preponderance but their political impact and significance in changing union behaviour.

\section{Discussion and Conclusions}

The desire of the Labour governments (1997-2001, 2001-) for unions and employers to reach voluntary deals without recourse to statutory means is bearing fruit. However, the manner in which this has occurred has been more complex, for the imminence of the procedures was shown to be important. Unions have recorded significant success in 
recent years in gaining new agreements, and there is no doubt that the number of new deals will continue to grow given the current extent of campaigns. Hundreds, covering nearly 530,000 workers, are underway, in which around 55,000 workers work in workplaces with over $50 \%$ density. There is also scope for further campaigns that do not have to start from scratch: Cully et al (1999:93) found 8\% of workplaces had a union presence but no recognition. In these, the average density is $23 \%$ with 'only' $44 \%$ being below $10 \%$. Some $85 \%$ of these are in the private sector. Metcalf (2002:30) concluded from LFS data for 2001 that there are around 700,000 union members not covered by recognition. Data from the CBI (1998:23) shows a similar picture. To this extent, the prospect for future growth looks bright.

But whether the degree of growth recorded to date will continue is dependent on the balance of union resources, employer response, and the legal and public policy context. Unions are generally underresourced and it remains unclear whether the financial return from recent membership growth outweighs costs of recruiting and servicing to allow further resources to be put into recognition campaigns. In terms of employers, the key issues revolve round a) using up the pool of easy 'victories' and facing the 'harder nuts to crack', b) whether increases in agreements create a normalising effect and c) whether employers without recognition are 'anti-union' or 'non-union' where the former refers to employers who respond to an actual, potential or hypothetical threats and the latter those who have merely never been previously 'troubled' by unions. Lastly, outcomes of CAC applications have been relatively favourable but the settlement embodied in the ERA remains unaltered despite its review in 2003.

Sceptics of union revitalisation (e.g. Machin 2000a, 2000b, cf. Metcalf 2002) may rightly ask whether the growth in new agreements constitutes the turning of a corner. In part, this depends on what benchmark is being set and over what time scale - back to 1979 levels of recognition in a decade, or something akin to the TUC's modest target of $1 \mathrm{~m}$ new members in the next five years (Guardian 14 September 1999)? Large-scale 
redundancies in organisations with recognition (including some of those who have signed new agreements since 1995), the concentration of recognition campaigns in areas of traditional strength and the continued growth of non-union sectors may suggest that unions in Britain are running very fast merely to stand still ${ }^{3}$. If this is not to prove the case, then not only will unions have to invest greater resources in high cost organising outside their traditional bases and increase their strike rate in recognition campaigns, but the 'shadow effect' of the statutory provisions in facilitating agreements will also have to be much greater than that of the previous provisions of 1976-1980 (Metcalf 2001, cf. Millward et al 2000:235) to create a virtuous circle between recognition and recruitment (Bain and Price 1983:18).

\section{References}

ACAS (1981, 1990-2002) Annual Report, ACAS London.

Bain, G.S. and Price, R. (1983) 'Union growth: dimensions, determinants, and destiny' in Bain, G.S. (ed) Industrial Relations in Britain, Basil Blackwell, Oxford, pp3-33.

Brook, K. (2002) 'Trade union membership: an analysis of data from the autumn 2002 LFS' Labour Market Trends, July, pp343-354.

CBI (1998, 1999, 2000, 2001) Employment Trends Survey, CBI, London.

Cully, M., Woodland, S., O'Reilly, A. and Dix, G. (1999) Britain at Work, as depicted by the 1998 Workplace Employee Relations Survey, Routledge, London.

Dibb Lupton Alsop (2000, 2002) Industrial Relations Survey, Gee, London.

Ewing, K. (2001) (ed) Employment Rights at Work: reviewing the Employment Relations Act 1999, Institute of Employment Rights, London.

Gall, G. (1993) 'What happened to single union deals?' Industrial Relations Journal, 24/1:7175.

Gall, G. (2003) 'Employer opposition to union recognition' in Gall, G. (ed) Union Organizing: campaigning for trade union recognition, Routledge, pp79-96.

Gall, G. and McKay, S. (1994) 'Trade union derecognition in Britain 1988-1994.' British Journal of Industrial Relations, 132/3:433-448.

Gall, G. and McKay, S. (1999) 'Developments in union recognition and derecognition in Britain 1994-1998' British Journal of Industrial Relations, 37/4:601-614.

Gall. G. and McKay, S. (2001) 'Facing 'fairness at work': union perception of employer opposition and response to union recognition' Industrial Relations Journal, 32/2:94-111.

Heery, E., Simms, M., Simpson, D., Delbridge, R., and Salmon, J. (2000a). 'Organising unionism comes to the UK', Employee Relations, 22/1:38-57.

Heery, E., Simms, M., Delbridge, R., Salmon, J. and Simpson, D. (2000b) 'The TUC's Organising Academy: an assessment', Industrial Relations Journal, 31/5:400-415.

\footnotetext{
3 A not inconsiderable part of the current growth in new agreements may merely be regarded as
} compensating for the previous 'losses' of those affected by derecognition in the 1980s and 1990s. 
Heery, E., Simms, M., Delbridge, R., Salmon, J. and Simpson, D. (2000c) 'Union organising in Britain: a survey of policy and practice', International Journal of Human Resource Management, 11/5:986-1007.

Heery, E., Simms, M., Delbridge, R., Salmon, J. and Simpson, D. (2003) 'Trade union recuitment policy in Britain: form and effects' in Gall, G. (ed) Union Organizing: campaigning for trade union recognition, Routledge, London, pp56-78.

Hendy, J. (2001) Union Rights ... and Wrongs: the reform of Britain's Anti-Union Laws, Institute of Employment Rights/Unison, London.

Incomes Data Services (2001) 'Union recognition widens' IDS Report 836:12-20.

Industrial Relations Services (2000) 'Due Recognition' IRS Employment Trends 712:4-11.

Industrial Relations Services (2002) 'Gaining recognition' IRS Employment Trends 745:7-13. LRD/TUC (1995-2003) Trade Union Trends/'Focus on recognition' Trade Union Trends, Trades Union Congress, London.

Machin, S. (2000a) 'How the mighty are fallen' CentrePiece, 5/2:28-30.

Machin, S. (2000b) 'Union decline in Britain' British Journal of Industrial Relations, 38/4:631646.

Metcalf, D. (2001) 'British union: dissolution or resurgence revisited' Centre for Economic Performance, LSE, Discussion Paper, No 493.

Metcalf, D. (2002) 'Unions: past, present and future' Centre Piece, 7/3:26-33.

Millward, N., Stevens, M., Smart, D. and Hawes, W. (1992) Workplace Industrial Relations in Transition, Dartmouth, Aldershot.

Millward, N., Bryson, A. and Forth, J. (2000) All Change at Work? British employment relations 1980-1998, as portrayed by the Workplace Industrial Relations Survey series, Routledge, London.

Morris, G. (2001) 'The Employment Relations Act 1999 and collective labour standards' International Journal of Comparative Labour Law and Industrial Relations, 17/1:63-76.

Snape, E. (1994) 'Union organizing in Britain: the views of local full-time officials.' Employee Relations, 16/8:48-62.

Towers, B. (1999) Developing Recognition and Representation in the UK: bow useful is the US model? Comparative Notes 3, Institute of Employment Rights, London.

Younson, F. (2002) 'Employers face scoring own goal' People Management, 7 March, p16. 